
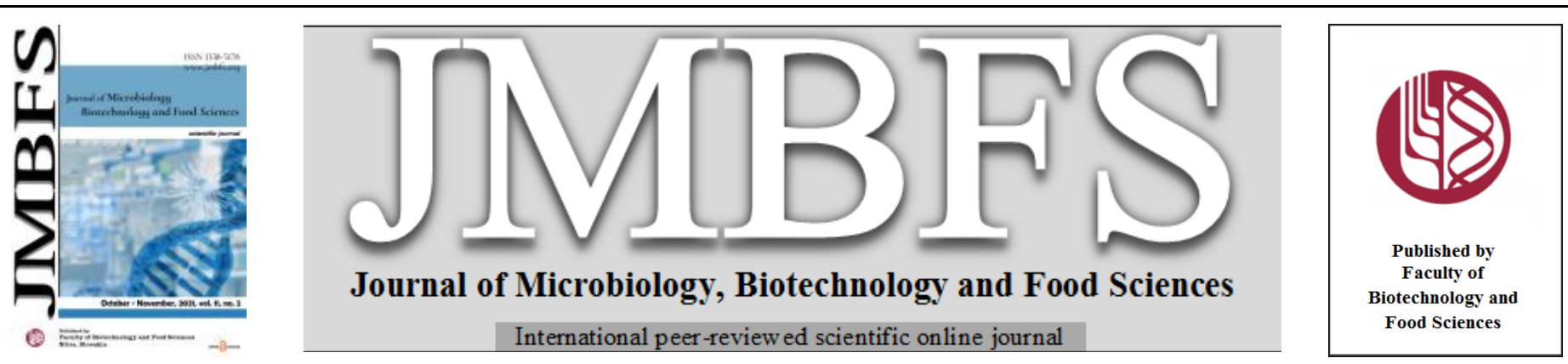

\title{
IMPROVEMENT OF PEARL MILLET (Pennisetum glaucum (L.) R. BR) PROLAMIN EXTRACTABILITY: CHROMATOGRAPHIC SEPARATION, CHARACTERIZATION AND FUNCTIONAL PROPERTIES
}

\author{
Rafika Bibi ${ }^{1,2}$, Hind Mokrane ${ }^{1 *}$, Khaled Khaladi ${ }^{1,2}$, Houria Amoura ${ }^{l}$ \\ Address(es): Prof. Hind Mokrane, PhD. \\ ${ }^{1}$ Laboratoire des produits bioactifs et de valorisation de la biomasse, Ecole Normale Supérieure, B.P. 92, 16050 Vieux-Kouba, Algiers, Algeria, phone \\ number:00213555253835. \\ ${ }^{2}$ Département des sciences de la matière, Université Alger 1 Benyoucef Benkhedda, Algiers, Algeria.
}

*Corresponding author: hind.mokrane@g.ens-kouba.dz or mokraneh2017@gmail.com

https://doi.org/10.15414/jmbfs.3674

\section{ARTICLE INFO}

Received 5. 9. 2020

Revised 18. 5. 2021

Accepted 28. 5. 2021

Published 1. 10. 2021

Regular article open $\partial_{\text {ACCESS }}$

\begin{abstract}
Pearl millet is a gluten free cereal resistant to drought, diseases and pests. The major protein fraction in pearl millet is prolamin the alcohol soluble fraction called pennisetin. Researches on the factors affecting pennisetin extraction and on its functional properties are still very scant. In this paper, the effect of temperature, reducing agents ( $\beta$-mercaptoethanol, dithiothreitol or sodium metabisulfite) and sodium hydroxide on pennisetin extraction was assessed. Samples were characterized by protein and amino acid (AA) analysis, SDSPage and reversed phase high-performance liquid chromatography (RP-HPLC). Pennisetin was extracted with high protein purity $(90.1 \%)$ from pearl millet grain flour (PMF) using $70 \%$ aqueous ethanol containing $1 \%$ sodium metabisulfite and $0.2 \%$ sodium hydroxide at $60^{\circ} \mathrm{C}$. SDS-Page confirmed pennisetin extraction and showed three subunits corresponding to the 27-, 22- and $12 \mathrm{kDa}-$ pennisetins. The percentage of essential amino acids in pennisetin $(68.55 \%)$ was higher than that in PMF (41.64\%). The hydrophobic character of pennisetin was confirmed by the presence of $45.49 \%$ of hydrophobic amino acids. Functional properties of pennisetin and PMF were investigated. Compared to PMF, pennisetin exhibited comparable oil and water binding capacities and higher foaming capacity and emulsifying activity index but with lower emulsion stability. Pennisetin functional properties were similar or lower relatively to common used proteins of wheat, sorghum, rice or peanut. Excluding water, oil binding and foam capacities, all the functional properties of pennisetin and PMF were significantly different $(\mathrm{p} \leq 0.05)$. The findings suggest increasing the use of pennisetin and PMF as nutritional and health promoting agent for vegans and celiac patients.
\end{abstract}

Keywords: Pearl millet, Effect of solvent, Pennisetin extraction, RP-HPLC, Functional properties

\section{INTRODUCTION}

Pearl millet [Pennisetum glaucum (L) R. Br.] is an important cereal crop classified sixth in term of consummation after wheat, rice, maize, barley and sorghum. Mostly it is grown in the arid and semi-arid tropics of south Asia, subSaharan Africa, China, Russia and Latin America (Bora et al., 2019; Ranasalva and Visvanathan, 2014; Sarita, 2016). Pearl millet is a drought-resistant crop with short growing season and good resistance to diseases and pests (Sarita, 2016). This gluten free cereal contains higher levels of essential amino acids (AA) than maize, rice, wheat and sorghum particularly methionine, cysteine and lysine (Akinola et al., 2017; Kasaoka et al., 1999; Mokrane, 2010). It is rich in dietary fibers, minerals, unsaturated acids and bioactive proteins (Bora et al., 2019; Esfandi et al., 2019; Gwamba et al., 2019). The protein concentration of pearl millet cultivars measured so far by several researchers varied from 9 to $17 \%$ and could reach for some samples 21\% (Kasaoka et al., 1999; Marcellino et al., 2002), while it varied from 6.8 to $7.4 \%$ in rice (Kasaoka et al., 1999), 11 to $16 \%$ in sorghum (Amoura et al., 2020; Mokrane et al., 2009) and 9.8-17.9\% in wheat (Hajas et al., 2018). As in almost all cereals, the most abundant seed protein fraction in pearl millet is prolamin: a class of alcohol-soluble proteins. This protein called pennisetin exceeded $40 \%$ of the total seed protein fraction. Like other cereal prolamins such as gliadin of wheat, kafirin of sorghum and zein of maize, pennisetin is rich in proline and other hydrophobic amino acids (Sainani et al., 1989; Schalk et al., 2017). SDS-Page of pennisetin exhibited three distinct bands with molecular masses of 27, 22 and 12kD (Marcellino et al., 2002; Ricks, 2007). Pennisetins were similar in composition and sequence to $\alpha$-prolamins from maize and sorghum, but this amino acid similarity was not as high to be called $\alpha$-, $\beta-, \gamma$ - or $\delta$-prolamins like sorghum kafirins or maize zeins (Adebiyi et al., 2017; Marcellino et al., 2002; Ricks, 2007).

In the two last decades, several studies have aimed to improve cereal protein extractability. Chromatography and SDS-Page were used to investigate the factors affecting cereal prolamin extraction such as extraction time, $\mathrm{pH}$, detergent type, reducing agent type and sample-to-solvent ratio (De Brier et al., 2015; Gessendorfer et al., 2010; Hamaker et al., 1995; Nalęcz et al., 2017; Park and Bean, 2003; Redant et al., 2017). To date only few studies have been conducted on the factor affecting pearl millet proteins extractability. Chandna and Matta (1990) characterized the seed protein extract of eight pearl millet lines by SDSPage and two dimensional electrophoresis. Later, Marcellino et al. (2002) reported the use of $55 \%$ aqueous isopropanol containing $\beta-\mathrm{ME}$ to extract pennisetins and characterized them by SDS-Page, bidimensional gel electrophoresis, MALDI-TOF/MS and RP-HPLC. In a similar study, Ricks (2007) adapted a method used for zein extraction to isolate pennisetin in a single extraction step and separated it using SDS-Page. Then, Mokrane (2010) characterized the protein fraction of eleven pearl millet cultivars by RP-HPLC, SE-HPLC and SDS-Page with emphasis to their prolamins without examining the impact of solvent, reducing agent and temperature.

Functional properties of pearl millet grain flours (PMF) or other millet varieties (Foxmail, Little, Barnyard, Koda, Proso and Finger) have been studied in their native form or as affected by processing (Akharume et al., 2020; Akinola et al., 2017; Ali et al., 2012; Hassan et al., 2007; Kamara et al., 2009; Kamara et al., 2010), however few studies aimed to investigate the functional properties of extracted pearl millet proteins particularly the prolamin fraction: pennisetin (Sainani et al., 1989; Taylor et al., 2016).

Due to the above mentioned reasons, the objective of this study was to investigate factors affecting pearl millet pennisetin extraction using RP-HPLC. Pennisetin was characterized by protein analysis, SDS-Page and AA analysis. Water and oil binding capacities, gelling, foaming and emulsifying properties of extracted pennisetin and PMF were investigated. 


\section{MATERIAL AND METHODS}

\section{Sample preparation}

Pearl millet samples from local cultivars of Bechna Beldia were harvested in 2014 from In-Salah situated in Tidikelt Region in Southern Algerian Sahara. This cultivars is growing under harsh conditions characterized by low rainfall.

Pearl millet grains were sorted and screened to remove undesirable material such as dust, broken grains and debris. The grains were then ground to flour in a commercial coffee grinder for 30s. The flour was further sieved over a $500 \mu \mathrm{m}$ sieve and then defatted with $n$-hexane $(1: 10 \mathrm{w} / \mathrm{v})$ for $24 \mathrm{~h}$ at room temperature with continuous stirring. PMF was recovered using an air Buchner funnel under a hood overnight. All chemicals and reagents were of analytical grade and from Sigma-Aldrich.

\section{Protein Analysis}

Protein analysis of extracted samples was performed by micro-Kjeldahl method of the Association of Official Analytical Chemists (AOAC) (AOAC, 1990) using 6.25 as conversion factor. Moisture content was determined according to American Association of Cereal Chemists (AACC) methods 44-15A (AACC. 2000). The amount of extracted protein was deduced on dry matter basis (dmb) from the initial protein content and the remaining protein content after extraction.

\section{Pennisetin extraction}

Pennisetin was extracted from $500 \mathrm{mg}$ of PMF (1h) using a modified method of Espinosa-Ramirez et al. (2016) previously described for sorghum kafirin extraction. The basic solvent consisted of $70 \%$ aqueous ethanol containing a reducing agent. The effect of three reducing agents at different concentrations was investigated: dithiothreitol (DDT) or Sodium metabisulfite (MBS) $(0.25,0.5$ or $1 \%(\mathrm{w} / \mathrm{v}))$ and $\beta-\operatorname{ME}(0.25,0.5$ or $1 \%(\mathrm{v} / \mathrm{v}))$.

Four temperatures $30,40,50$ and $60^{\circ} \mathrm{C}$ were tested. The effect of adding Sodium hydroxide $(\mathrm{NaOH})$ was assessed at different concentrations varying from 0 to $0.4 \%(\mathrm{w} / \mathrm{v})$. All the obtained suspensions were centrifuged at $3000 \times \mathrm{g}$ for $5 \mathrm{~min}$ and the supernatants were saved for further analysis by RP-HPLC and SDS-Page. For RP-HPLC analysis, samples were filtered $(0.45 \mu \mathrm{m}$, nylon, Millipore) before storage in the freezer.

For protein and AA analysis and functional properties determination, pennisetin was precipitated and dried from the supernatant with the highest protein content as described in the following. First, ethanol concentration in the supernatant was brought below $20 \%(\mathrm{v} / \mathrm{v})$ by adding distilled water. $\mathrm{pH}$ was then adjusted to 4.5 with hydrochloric acid $\mathrm{HCl}(1 \mathrm{M})$. The suspension was centrifuged at $3000 \times \mathrm{g}$ for $10 \mathrm{~min}$ and the obtained residue was rinsed 3 times with distilled water and dried in the oven at $40^{\circ} \mathrm{C}$ overnight. All the extractions were repeated at least three times.

\section{SDS-Page}

Pennisetin extracted with or without reducing agent was dispersed in a Tris(hydroxymethyl) aminomethane-hydrochloric acid (Tris-HCl) sample buffer at $\mathrm{pH} 6.8$ containing $125 \mathrm{mM}$ Tris, $30 \%(\mathrm{w} / \mathrm{v})$ glycerol, $4.0 \%(\mathrm{w} / \mathrm{v})$ sodium dodecyl sulfate (SDS) and $0.002 \%(w / v)$ bromophenol blue. The samples were boiled for $5 \mathrm{~min}$ and centrifuged at $11,000 \times \mathrm{g}$ for $3 \mathrm{~min}$. Electrophoresis was carried out in $20 \%$ (w/v) polyacrylamide mini-gel using a PhastSystem unit (GE Healthcare, Uppsala, Sweden), then the gel was silver-stained using the GE Healthcare development Technique file no. 210. The molecular markers (MM) (GE Healthcare) used were $\alpha$-lactalbumin $(14.4 \mathrm{kDa})$, trypsin inhibitor $(20.1$ $\mathrm{kDa})$, carbonic anhydrase (30 kDa), ovalbumin (43 kDa), bovine serum albumin (BSA) $(67 \mathrm{kDa})$ and phosphorylase $(94 \mathrm{kDa})$.

\section{Amino acid composition}

AA composition of PMF and pennisetin were determined using a high performance anion exchange chromatography with an Integrated Pulsed Amperometric Detection (IPAD) equipped with a gold electrode on an analytical AminoPac PA 10 analytical column $(2 \times 250 \mathrm{~mm})$ preceded by an AminoPac PA 10 guard column $(2 \times 50 \mathrm{~mm})$ (AAA-Diect Amino Acid Analyzer, Dionex Corporation, Sunnyvale, CA, USA). The operating conditions were previously described by Rombouts et al. (2009) and Mokrane et al. (2010).

\section{Reversed Phase High Performance Liquid Chromatography (RP-HPLC)}

Aliquots $(100 \mu 1)$ of the pennisetin were loaded on a Supelco C18 column $(5 \mu \mathrm{m}$ $4.6 \times 250 \mathrm{~mm}, 300 \AA$, Machery-Nagel, Düren, Germany) preceded by a Supelco C18 guard column $(2 \times 50 \mathrm{~mm})$ (Machery-Nagel, Düren, Germany). The HPLC system (Shimadzu, Tokyo, Japan) was equipped with LC10 ATVP pump and a SPD 10AVP UV-VIS detector. A Rheodyne 7725 sample injector (Coati, CA, USA) was fitted with a $20 \mu \mathrm{l}$ sample loop. The column was equilibrated at sample loading conditions $25 \%$ solvent B (Acetonitrile $(\mathrm{ACN})$ containing $0.1 \%(\mathrm{v} / \mathrm{v})$
Trifluoroacetic acid (TFA) and solvent A (demineralized water containing $0.1 \%$ (v/v) TFA). Pennisetin fractions were separated at $50^{\circ} \mathrm{C}$ with a flow rate of 0.5 $\mathrm{mL} / \mathrm{min}$ using the following gradient from 0 to $40 \mathrm{~min}, 25 \% \mathrm{~B}$, from 40 to 46 $\mathrm{min}, 72 \% \mathrm{~B}$ and from 46 to $70 \mathrm{~min}, 80 \% \mathrm{~B}$. The separation was monitored by recording extinction at $214 \mathrm{~nm}$ during $70 \mathrm{~min}$. For each sample RP-HPLC analysis were repeated at least three times.

\section{Functional properties of pennisetin and pearl millet whole grain flour}

\section{Gelling properties}

The least gelling concentration (LGC) determination of PMF and pennisetin at different concentrations $2,4,6,8,10,12,14,16,18$, and $20 \%(\mathrm{w} / \mathrm{v})$ was carried out according to the method of Sathe et al. (1982). Samples were heated for $1 \mathrm{~h}$ in boiling water followed by cooling in ice and further cooling for $2 \mathrm{~h}$ at $4{ }^{\circ} \mathrm{C}$. LGC was defined by the concentration of sample that did not fall down or slip when the test tube was inverted.

\section{Water binding capacity and oil binding capacity}

Water binding capacity (WBC) and oil binding capacity (OBC) were determined using the method of Beuchat (1977). One gram of PMF or pennisetin was weighed into a pre-weighed centrifuge tube and mixed with $10 \mathrm{~mL}$ of distilled water for WBC or $10 \mathrm{~mL}$ of corn oil (Sigma-Aldrich) for OBC. Samples were vortexed for one min and allowed to stand for $30 \mathrm{~min}$ at $25 \pm 2^{\circ} \mathrm{C}$ before being centrifuged at $4000 \times \mathrm{g}$ for $25 \mathrm{~min}$. Excess water was removed by inverting the tubes over absorbent paper and samples were dried before being weighted. WBC was expressed as grams of water per gram of dry sample and $\mathrm{OBC}$ was expressed as grams of oil per gram of dry sample.

\section{Foaming properties}

Foaming capacity (FC) and foam stability (FS) of PMF and pennisetin were determined according to the method of Coffman and Garcia (1977). FC was measured in term of percentage of volume increase after whipping reported to original volume of the liquid. Foam stability (FS) was expressed as percentage of foam volume remaining after $1,5,10,20,30,40,50$ and 60 min related to initial foam volume at room temperature $25 \pm 2^{\circ} \mathrm{C}$.

\section{Emulsifying properties}

The emulsifying properties of PMF and pennisetin were expressed by the emulsifying activity index (EAI) and emulsion stability (ES) as previously defined by Pearce and Kinsella (1978) using the turbidimetric method. EAI $\left(\mathrm{m}^{2} / \mathrm{g}\right)$ was measured after 0,10 and $30 \mathrm{~min}$ and calculated as follows:

$\operatorname{EAI}\left(\frac{\mathrm{m}^{2}}{\mathrm{~g}}\right)=\frac{2 \times 2.303 \times \mathrm{A} \times \mathrm{D}}{\Phi \times \mathrm{L} \times \mathrm{C}}$

Where $A$ is the absorbance at $500 \mathrm{~nm}, \mathrm{D}$ is the dilution factor $(\mathrm{D}=100), \Phi$ is the oil volumetric fraction $(\Phi=0.25), \mathrm{L}$ is the curve path length $(\mathrm{L}=0.01 \mathrm{~m}), \mathrm{C}$ is the protein concentration of the sample $\left(\mathrm{g} / \mathrm{m}^{3}\right)$.

$\mathrm{ES}(\%)$ is defined by the percentage of EAI remaining after 0,10 and $30 \mathrm{~min}$. PMF and pennisetin functional properties were analyzed at least in duplicate.

\section{Data treatment}

All statistical analyses were performed using the Statistical Analysis System R 4.0.2. The extraction procedure and the functional properties were carried out at least three times. The analysis of variance of AA composition, reducing agent, $\mathrm{NaOH}$ concentration, temperature, $\mathrm{WBC}, \mathrm{OBC}$, foaming and emulsifying properties of pennisetin and PMF were performed with a Tukey multiple comparison procedure on a 5\% significance level (R Core Team, 2020).

\section{RESULTS AND DISCUSSION}

\section{Protein contents}

High protein content was obtained in PMF analyzed in this study up to $18.22 \pm$ $0.80 \%$ on dmb with low humidity of $9.0 \pm 0.29 \%$. These results are probably deeply related to the drought growing conditions in the city of In-Salah situated in South Algeria. This high protein pearl millet cultivars content is locally known to support harsh growing conditions such as low rainfall and hyper arid climate. In the past ten years (2009-2019) the minimal and maximal average temperatures were 6 to $45^{\circ} \mathrm{C}$, respectively and the minimal and maximal average rainfall were 0.20 and $3 \mathrm{~mm}$, respectively. According to Ozturk and Aydin (2004) climate and environment have a remarkable effect of the cereal grain yield, ash and protein content. The highest protein content was obtained in the most water stressed accessions. These conclusions were in agreement with the pearl millet cultivars analyzed in the present study. 
The level of protein in the pennisetin extract was $90.1 \pm 0.20 \%$ on $\mathrm{dmb}$. To the best of our knowledge, this is the highest level of protein obtained in pennisetin extract to date probably because this extraction procedure initially applied for sorghum kafirin by Espinosa-Ramirez et al. (2016), was applied on pearl millet proteins for the first time.

\section{Amino acid composition}

Table 1 shows the AA composition of PMF and extracted pennisetin expressed in $\mathrm{g}$ of amino acid by $100 \mathrm{~g}$ of crude protein (\%). All AAs in PMF and pennisetin were significantly different $(\mathrm{p} \leq 0.05)$ in individual AA concentration. The percentage of essential AA in the pennisetin extract $(68.55 \%)$ was higher than that in the PMF flour $(41.64 \%)$.

Pennisetin was rich in Lysine $(21.44 \%)$, while in the PMF the percentage of Lysine was 11 times lower, this may improve the nutritional quality of the extracted pennisetin. In a previous study, Chandna and Matta (1990) have also found high level of Lysine in the prolamin fraction of pearl millet exceeded only by its level in the albumin fraction. They assumed that in stread of screening high lysine pearl millet lines, it would be better to screen high prolamin pearl millet lines.

As shown in table 1, pennisetin is also rich in hydrophobic AA: Valine $(22.44 \%)$ and Proline $(10.24 \%)$. Pennisetin was made up of high percentages $(45.49 \%)$ of hydrophobic AA (Alanine, Isoleucine, Leucine, Methionine, Phenylalanine, Proline and Valine), the remaining AA were basic $(34.51 \%)$, non polar $(12.80 \%)$ and acid $(7.20 \%)$. Such results show and confirm the hydrophobic properties of pennisetin.

Based on the AA composition of the FAO/WHO (1991) reference protein, lysine and methionine were the most limiting essential amino acid in PMF while Threonine, Phenylalanine and Methionine were the most limiting AA in pennisetin. As compared to sorghum (Mokrane et al., 2010), wheat (Abdel-Aa and Hucl, 2002) and maize (Harrigan et al., 2009), PMF was richer in Lysine, Threonine, Isoleucine, Valine, Serine and Asparagine/aspartic acid and poorer in Proline. The high levels of proteins and essential AA in the extracted pennisetin suggest its potential use as a good source of bioactive peptides or as a peptide concentrate for food. The higher level of hydrophobic AA in pennisetin could enable its potential use as coating material for hydrophobic bioactive compounds.

Table 1 Amino acid composition of pearl millet grain flour and extracted pennisetin expressed in $\mathrm{g}$ of amino acid by $100 \mathrm{~g}$ of crude protein $(\%)$

\begin{tabular}{lccc} 
& $\begin{array}{c}\text { Pearl millet } \\
\text { grain flour }\end{array}$ & Pennisetin & FAO/WHO \\
\hline Essential amino acids (\%) & & & \\
\hline Lysine*** & $2.38 \pm 0.05$ & $21.44 \pm 0.00$ & 5.8 \\
Threonine*** & $6.25 \pm 0.01$ & $0.00 \pm 0.00$ & 3.4 \\
Phenylalanine*** & $5.13 \pm 0.01$ & $0.55 \pm 0.56$ & 6.3 \\
Isoleucine*** & $4.13 \pm 0.02$ & $7.74 \pm 0.29$ & 2.8 \\
Leucine*** & $14.80 \pm 0.22$ & $4.38 \pm 1.47$ & 6.6 \\
Valine*** & $5.28 \pm 0.02$ & $22.44 \pm 0.44$ & 3.5 \\
Methionine*** & $1.39 \pm 0.17$ & $0.07 \pm 0.14$ & 2.5 \\
Tyrosine*** & $2.47 \pm 0.11$ & $11.92 \pm 0.27$ & \\
\hline Total Essential amino & $\mathbf{4 1 . 6 4}$ & $\mathbf{6 8 . 5 5}$ & \\
acids (\%) & & & \\
\hline Non essential amino acids (\%) & & \\
\hline Arginine*** & $10.99 \pm 0.11$ & $7.20 \pm 0.41$ & \\
Alanine*** & $7.33 \pm 0.12$ & $0.07 \pm 0.63$ & \\
Glycine*** & $2.66 \pm 0.02$ & $0.68 \pm 0.09$ & \\
Cystine** & $0.44 \pm 0.08$ & $0.21 \pm 0.05$ & \\
Proline*** & $6.12 \pm 0.20$ & $10.24 \pm 0.53$ & \\
Serine*** & $4.21 \pm 0.03$ & $0.00 \pm 0.00$ & \\
Glutamic acid/ & $17.47 \pm 0.24$ & $0.65 \pm 1.99$ & \\
Glutamine*** & & & \\
Aspartic acid/ & $7.24 \pm 0.10$ & $6.55 \pm 0.54$ & \\
Asparaginine*** & $2.04 \pm 0.04$ & $5.86 \pm 0.16$ & \\
Histidine*** & & & \\
Total non & & & \\
\hline
\end{tabular}

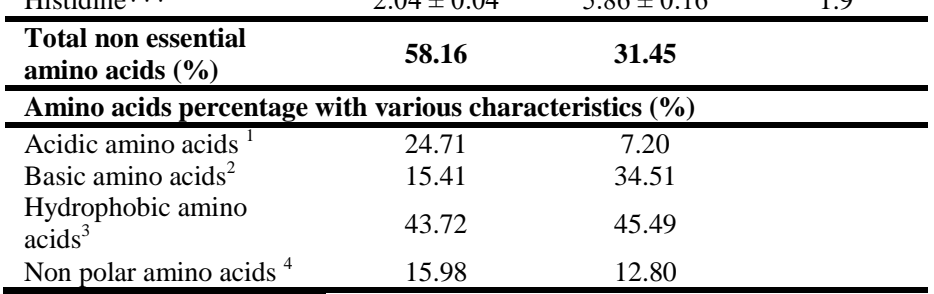

Legend: Values indicate the mean of three replicates \pm standard deviation. ${ }^{1}$ Acidic: Glutamic acid, Aspartic acid, ${ }^{2}$ Basic: Lysine, Arginine, Histidine, ${ }^{3}$ Hydrophobic: Alanine, Isoleucine, Leucine, Methionine, Phenylalanine, Proline, Valine, ${ }^{4}$ Non polaire: Glycine, Serine,

Threonine, Tyrosine, Cysteine. ${ }^{5} \mathrm{FAO} / \mathrm{WHO}(1991) . * * * \mathrm{p} \leq 0.001, * * \mathrm{p} \leq 0.01, * \mathrm{p} \leq 0.05$.

\section{SDS-Page}

The pearl millet prolamins showed SDS-PAGE profiles comparable to those in previous reports (Hadimani et al., 2001; Marcellino et al., 2002). Figure 1 , lanes 1 and 2 show the silver-stained SDS-PAGE profile of pennisetin extracted with or without reducing agent, respectively. Three main bands, corresponding to the 27-, 22- and $12 \mathrm{kDa}$-pennisetins subunits appeared on both lanes 1 and 2. As shown in Figure 1 lane 1, pennisetin subunits could be extracted without adding any reducing agent using $70 \%$ aqueous ethanol at $60^{\circ} \mathrm{C}$. However, this unreduced pennisetin fraction included also high molecular weight (HMW) proteins probably corresponding to polymers, trimers and dimers of pennisetin subunits The addition of reducing agent led to almost total disappearance of these HMW in lane 2, a faint band remained at $40 \mathrm{kDa}$ which is probably a dimer of the 27 and $12 \mathrm{kDa}$-pennisetins. The 27, 22 and $12 \mathrm{kDa}$-pennisetin subunits appeared more accentuated in the reduced fraction (Figure 1, lane 2) than that in the unreduced fraction (Figure 1, lane 1). SDS-Page of pennisetin showed that adding reducing agent improved the pennisetin subunits extractability markedly; this may indicate the presence of SS cross-linked pennisetins.

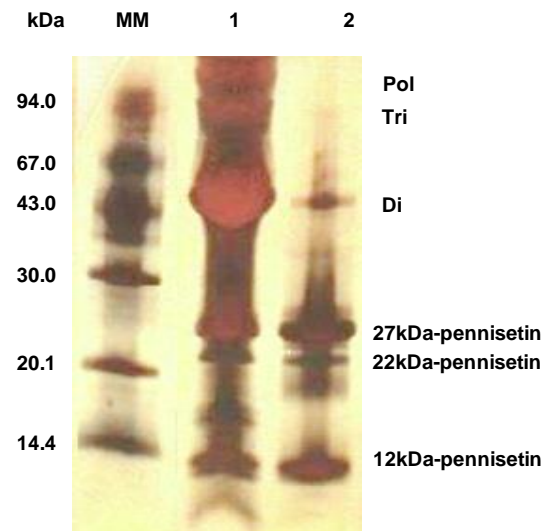

Figure 1 SDS-PAGE of pearl millet pennisetin: Lane 1: Pennisetin extracted without reducing agent; Lane 2: Pennisetin extracted with $\beta$-mercaptoethanol as reducing agent, lane MM: Molecular markers. The masses of the MM are indicated on the left side. The 27-, 22- and 12kDa-pennisetin monomers for pear millet as well as the corresponding polymers (Pol), trimers (Tri) and dimers (Di) are indicated.

\section{Reversed phase high performance liquid chromatography (RP-HPLC)}

Protein extractability is highly affected by the solvent used, adding reducing agent, the experimental protocol and the conditions such as temperature and $\mathrm{pH}$. In the following, to improve pennisetin extractability the effect of three reducing agents, temperature and $\mathrm{NaOH}$ was investigated by RP-HPLC.

\section{Effect of reducing agent}

The effect of reducing agents on pennisetin extractability was the first factor investigated. Figure $2 \mathrm{a}$ shows the total peak area of RP-HPLC chromatogram of pennisetin using three reducing agents (MBS, $\beta-\mathrm{ME}$ and DTT) at various concentrations; all the values were highly significant at $\mathrm{p} \leq 0.001$. Pennisetin could be extracted without reducing agent but at low level. Adding increasing amount of MBS allowed extracting higher level of pearl millet proteins. Controversially, adding increasing amount of both $\beta$-ME and DTT reduced the level of extracted pennisetin. Addition of $1 \%$ MBS allowed to extract the highest level of pearl millet protein. DTT extracted lower amounts of protein than MBS, with an optimal concentration of $0.25 \%$ DTT. $\beta$-ME extracted the least amount of proteins. Such findings show that MBS is more effective for pearl millet protein extraction than the other reducing agents. In addition, MBS is a food grad ingredient that could be used in food applications of pearl millet proteins without causing side effects (Bean et al., 2006). The amount of protein extracted with $1 \%$ MBS was then chosen for use in all the following experiments.

The effect of reducing agent on cereal protein extractability has been extensively investigated by several researchers, such as Redant $\boldsymbol{e t}$ al. (2017) for rye protein and by Bean et al. (2006), Hamaker et al. (1995) and Mokrane et al. (2009) for sorghum protein and Celus et al. (2006) for barley protein. In a previous study, Akharume et al. (2020) extracted the prolamin fraction of two proso millet cultivars after albumin, globulin and glutelin extraction using 70\% Isopropyl Alcohol at room temperature and without adding reducing agent, they obtained low protein recovery of $54-60 \%$ with a prolamin extract containing $64.3-77.3 \%$ of protein. However to the best of our knowledge, few studies have aimed to investigate the effect of reducing agent on pearl millet protein extraction Marcellino et al, (2002) used 55\% isopropanol in the presence of $2 \%$ B- ME without mentioning the protein recovery yield. Hadimani et al. (2001) reported the protein distribution of three pearl millet cultivars in the albumin, globulin, 
glutelin and prolamin fractions, the later constituting more than $50 \%$ of total protein. To date the highest protein contents in pennisetin extracted did not exceed 60\% (Mokrane, 2010). In the present study, using 1\% of MBS allowed obtaining high protein concentrate $(90.1 \%)$ with high purity.

\section{Effect of $\mathrm{NaOH}$ concentration}

Cereal prolamins extraction was reported to be markedly affected by alkaline $\mathrm{pH}$ (Hamaker et al., 1995; Park and Bean, 2003; Pontieri et al., 2019). To assess pennisetin extractability at various $\mathrm{pH}$, increasing amount of $\mathrm{NaOH}$ ranging from 0 to $0.4 \%$ (w/v) were added to the previous extraction procedure using $70 \%$ aqueous ethanol at $60^{\circ} \mathrm{C}$ in the presence of $1 \% \mathrm{MBS}$ as reducing agent. Figure $2 \mathrm{~b}$ shows the effect of $\mathrm{NaOH}$ concentration on pennisetin extraction expressed by the relative areas of RP-HPLC chromatograms. A highly significant difference was obtained in $\mathrm{NaOH}$ concentration $(\mathrm{p} \leq 0.001)$. $\mathrm{NaOH}$ increased the relative peak area of solubilized pennisetin by up to $0.2 \%$ of $\mathrm{NaOH}$. However, an increase in $\mathrm{NaOH}$ concentration of more than $0.2 \%$ decreased the amount of extracted proteins. Park and Bean (2003) also observed this decrease in sorghum kafirin extraction. Pearl millet prolamins were therefore best extracted at an alkaline medium without exceeding $0.2 \% \mathrm{NaOH}$.
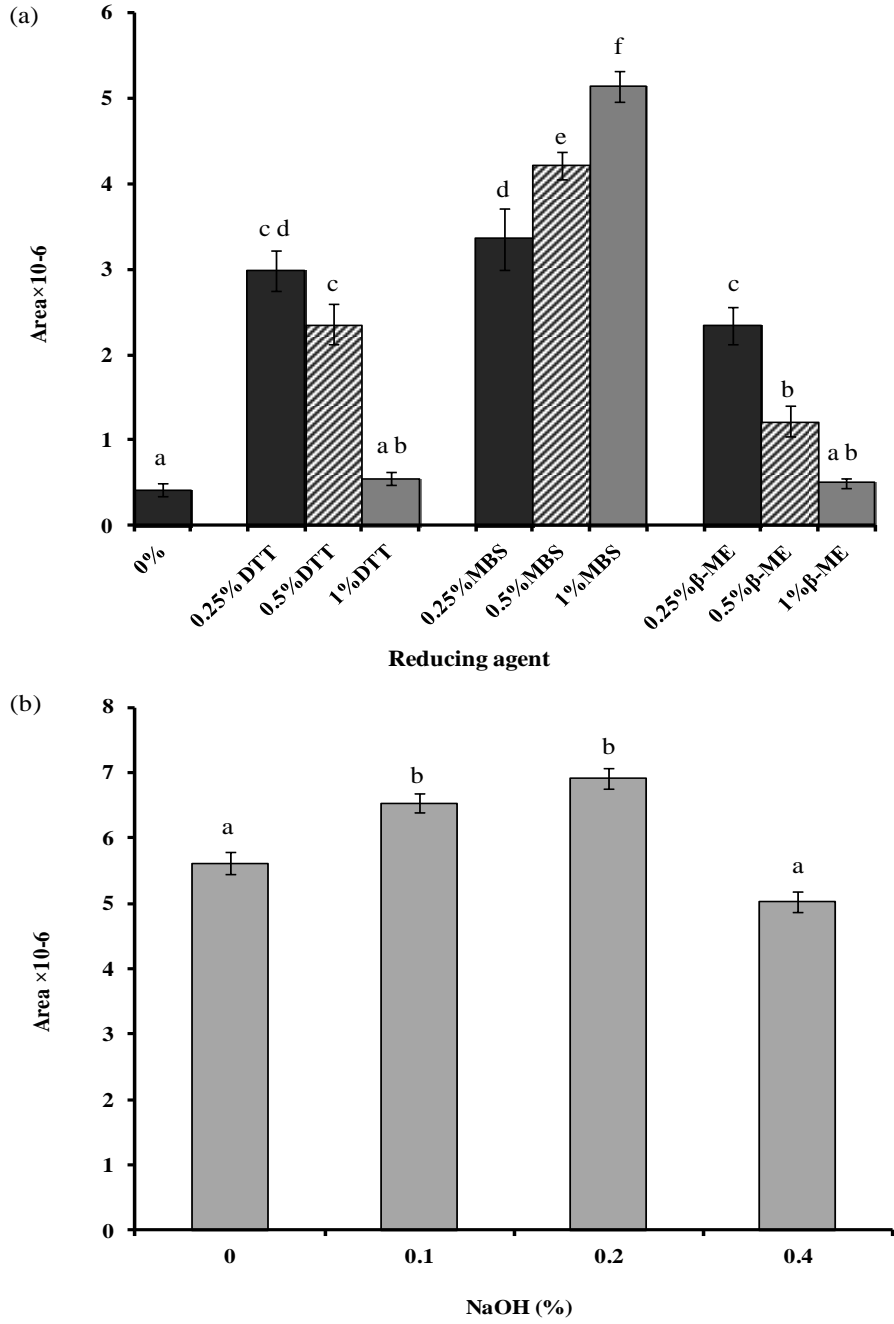

Figure 2 (a) Effect of reducing agent on extraction of pearl millet proteins Samples were extracted with different concentrations and types of reducing agents in $70 \%$ aqueous ethanol. Samples were analyzed using RP-HPLC, and total peak area was calculated. (b) Effect of $\mathrm{NaOH}$ on extraction of pearl millet proteins. Samples were extracted with different concentrations of $\mathrm{NaOH}$ in $70 \%$ aqueous ethanol containing $1 \% \mathrm{MBS}$ at $60^{\circ} \mathrm{C}$. Samples were analyzed using RPHPLC, and total peak area was calculated. Values indicate the mean of three replicates. Values with the same letter are not significantly different from each other $(\mathrm{p} \leq 0.05)$

\section{Effect of temperature}

Pennisetin solubility is affected by heat. The effect of increasing extraction temperature was investigated in the following. The extraction procedure was performed with $70 \%$ aqueous ethanol and $0.2 \% \mathrm{NaOH}$ at increasing temperature $30,40,50$ and $60^{\circ} \mathrm{C}$ in the presence of $1 \%$ MBS as reducing agent. Figure $3 \mathrm{a}$ shows the effect of temperature on the extractability of pearl millet proteins expressed by RP-HPLC area. RP-HPLC separations were compared both quantitatively by measuring peak area (Figure $3 \mathrm{a}$ ) and qualitatively by visually comparing RP-HPLC patterns (Figure 3b).

The relative amount of total extracted pennisetin appeared to be extremely affected by increasing temperature and highly significant difference was obtained $(\mathrm{p} \leq 0.001)$. In this manner at $60^{\circ} \mathrm{C}$ the extractable amount of protein increased almost three times compared to that extracted at $30^{\circ} \mathrm{C}$. This is probably due to the high protein folding in the pearl millet proteins. In previous works, FTIR showed that pennisetin the major protein fraction in pearl millet is arranged in secondary and tertiary structures which may be destroyed or highly reduced during heating (Bugs et al. 2004). Subsequently reducing agent along with heating might increase the solubility of pennisetin particularly at $60^{\circ} \mathrm{C}$. Higher temperatures may cause pennisetin unfolding and may reduce its functional properties Comparable results were obtained during sorghum prolamin extraction namely kafirin in several research (Amoura et al., 2020; Espinosa-Ramirez et al. 2016; Mokrane et al., 2009; Park and Bean, 2003).

(a)
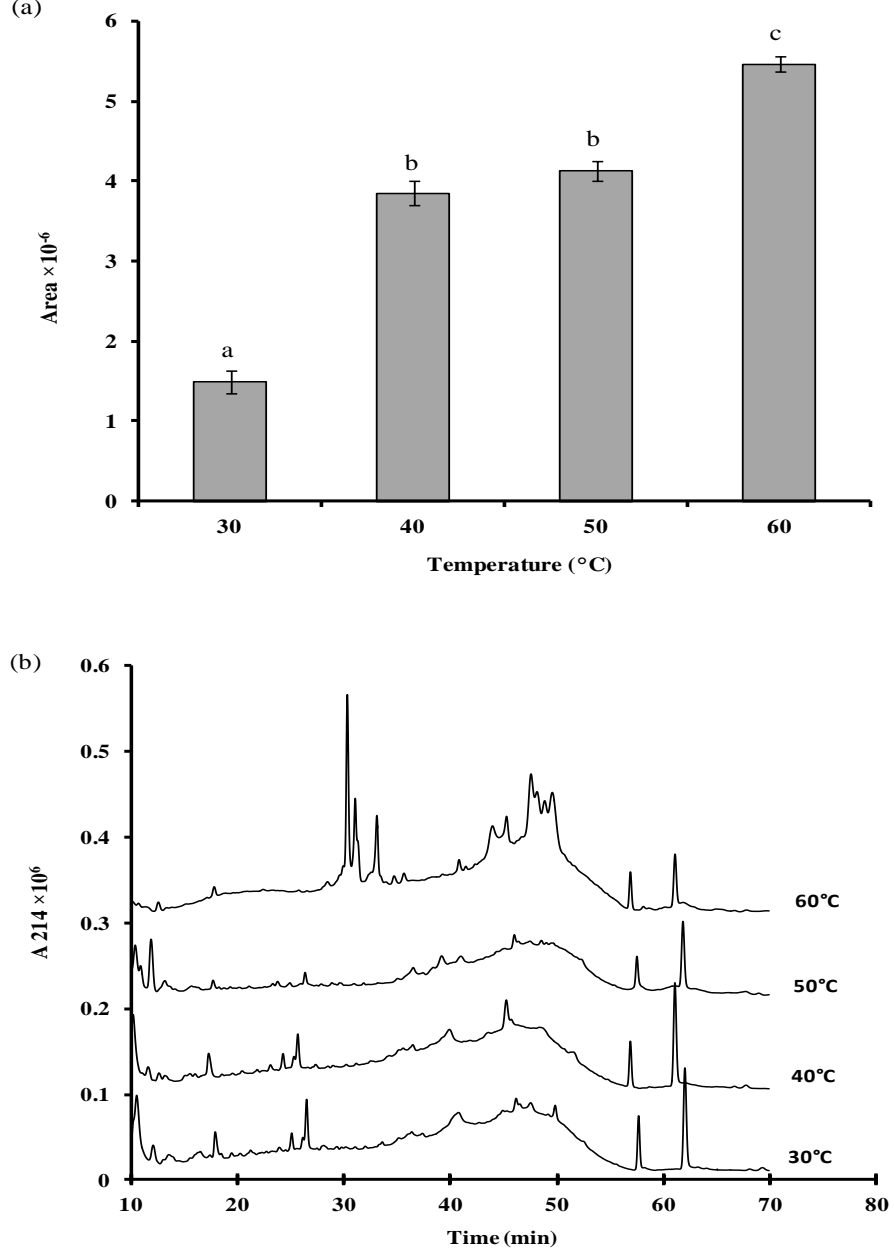

Figure 3 (a) Effect of temperature on extraction of pearl millet proteins. Samples were extracted at different temperature in $70 \%$ aqueous ethanol containing $1 \%$ MBS. Samples were analyzed using RP-HPLC, and total peak area was calculated. (b) Reverse phase-High performance liquid chromatography (RPHPLC) profiles of proteins extracted from pearl millet with $70 \%$ aqueous ethano containing $1 \% \mathrm{MBS}$ at $30,40,50$ and $60^{\circ} \mathrm{C}$. Absorbance was recorded at $214 \mathrm{~nm}$. Values indicate the mean of three replicates. Values with the same letter are not significantly different from each other $(\mathrm{p} \leq 0.05)$

\section{Water binding capacity and oil binding capacity}

The measurement of $\mathrm{WBC}$ and $\mathrm{OBC}$ of pennisetin and PMF is required for their potential use as texture and flavor enhancers (Zayas, 1997). Figure 4 shows the WBC and OBC of pennisetin and PMF, the obtained values were not significantly different $(\mathrm{p} \leq 0.05)$. WBC and $\mathrm{OBC}$ of pennisetin were comparable but slightly lower than that of PMF. Pennisetin was likely denatured during extraction and precipitation at $\mathrm{pH}$ 4.5. In a similar study, Wu et al. (2009) obtained the same decrease in WBC and $\mathrm{OBC}$ of peanut proteins extracted by strong acid or alkali and alcohol solvent compared to peanut flour. As shown in Table 1 the amount of acidic AA and non polar AA was lower in pennisetin than those in PMF, this is probably due to their destruction during alkali extraction. WBC of PMF were in the same range of those obtained for pearl millet flour by 
Ali et al. (2012) and Oshodi et al. (1999) and lower than that obtained by Akinola et al. (2017). WBC of both pennisetin and PMF were lower than those obtained for kafirin and sorghum flour (Amoura et al., 2020; Espinosa-Ramirez et al. 2016) and for quinoa flour $(3.94 \pm 0.06 \mathrm{~g} / \mathrm{g})$ and quinoa protein $(1.3 \pm 0.06$ g/g) (Dakhili et al. 2016). Lower WBC is desirable for thinner gruels production (Simwaka et al., 2017). Pennisetin OBC was lower than that of kafirin, while OBC of PMF was higher $(1.46 \pm 0.05 \mathrm{~g} / \mathrm{g})$ than those obtained for PMF by Ali $\boldsymbol{e} t$ al. (2012), defatted rice flour $(1.10 \pm 0.06 \mathrm{~g} / \mathrm{g})$ and defatted wheat flour $(1.26 \pm$ $0.15 \mathrm{~g} / \mathrm{g}$ ) by Joshi et al. (2015). OBC of PMF was almost two times higher than sorghum flour (Amoura et al., 2020) and in the same range of soybean flour (Ali et al., 2012; Joshi et al., 2015). Both pennisetin and PMF showed interesting WBC and $\mathrm{OBC}$ in the same range of other protein sources, which could allow their use as non gluten food additive in food products for better texture and flavour.

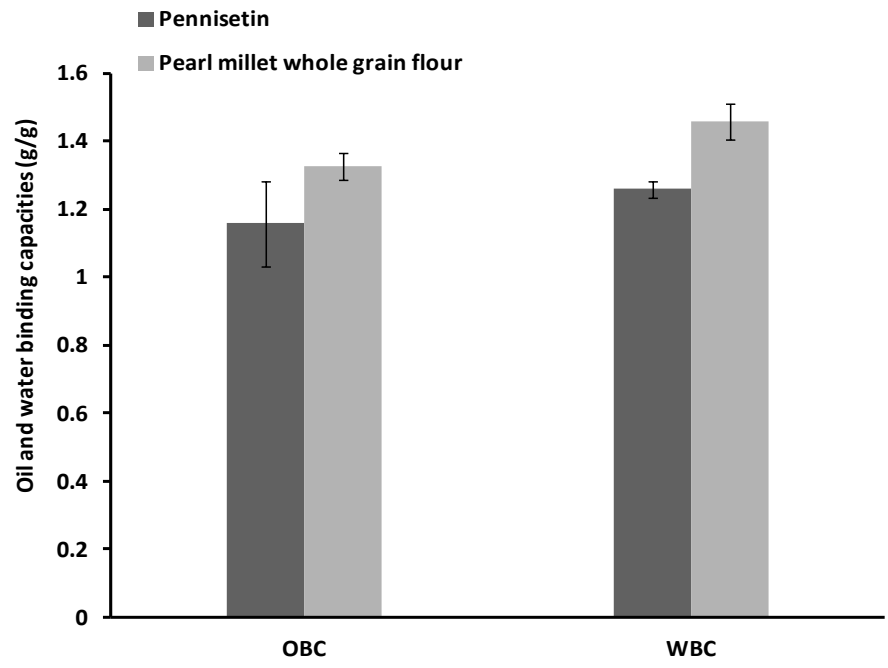

Figure 4 Water binding capacity (WBC) and oil binding capacity (OBC) of pennisetin and pearl millet whole grain flour. Values indicate the mean of three replicates.

\section{Gelation properties}

The gelation properties of pennisetin and PMF at increasing flour concentration are shown in Table 2. Pennisetin did not form gel while PMF began to form a ge at a concentration of $8 \%$ and gelled completely at $14 \%$. LGC of PMF were significantly different at $\mathrm{p}<0.01$. In previous studies, Ali et al. (2012) and Oshodi et al. (1999) obtained lower LGC of PMF $12 \%$ and $8 \%$, respectively. However, PMF showed better gelation properties than sorghum flour (16\%) (Amoura $e$ al., 2020), rice flour (18\%) (Joshi et al., 2015) and wheat flour (20\%) (Dhankhar et al., 2019) . Pennisetin could be used as co-gelling agent whereas PMF could be used as gluten free additive for better food sensorial perception and texture.

\section{Foaming properties}

Good foaming properties of food proteins are required for cakes, ice cream and whipped desserts. Foam enhances flavour dispersion, smoothness, lightness and palatability of food. Table 3 summarizes the foaming properties (FC and FS) of pennisetin and PMF. Among time, FC of pennisetin and PMF were not significantly different at $p \leq 0.05$, while FS of pennisetin was highly significant $(\mathrm{p} \leq 0.001)$ and FS of PMF was significantly different $(\mathrm{p} \leq 0.05)$. Both pennisetin and PMF had the ability to form foam with FC of $18.89 \pm 1.11 \%$ and $7.78 \pm 1.57$ $\%$, respectively. FC of pennisetin was 2.43 times higher than PMF. FS of pennisetin and PMF decreased rapidly in the first 5 minutes to reach 88.19 and $70.83 \%$, respectively. Afterwards, FS remained stable for $50 \mathrm{~min}$. FS of pennisetin and PMF decreased again rapidly to 58.33 and $41.67 \%$. Similarly Ali et al. (2012) and Oshodi et al. (1999) found better PMF FC 24\% and $11.3 \%$, respectively with lower FS (16.69\%) while Akinola et al. (2017) reported lower FC $(3.36 \%)$ and FS $(4.69 \%)$ respectively.

Compared to other cereals, FC of sorghum flour were higher $14 \%$ than that of PMF and kafirin formed negligible and unstable foam (Amoura et al., 2020). Foaming properties of pennisetin and PMF were lower than quinoa protein isolate (Dakhili $\boldsymbol{e t}$ al. 2016), soybean protein isolate and soybean flour (Ali $\boldsymbol{e t}$ al., 2012; Joshi et al., 2015). One possible raison could be the high ordered globular proteins in the native PMF. $\mathrm{pH}$, salt contents and protein concentration might improve foaming properties of pennisetin and PMF. As suggested by Akinola $\boldsymbol{e t}$ al. (2017) further studies should be undertaken to explain the low foaming properties of pearl millet flour. The effect of protein concentration, $\mathrm{pH}$, salt concentration should be studied to improve the FC and FS of pennisetin and PMF.

\section{Emulsifying properties}

Good emulsifying properties are desired for oil emulsions stabilization by preventing droplets coalescence and increasing surface hydrophobocity. Figure 5 illustrates the emulsifying properties (EAI and ES) of pennisetin and PMF. EAI of pennisetin was highly significant $(\mathrm{p} \leq 0.001)$, while EAI of PMF was only significantly different ( $\mathrm{p} \leq 0.05$ ), among time. Pennisetin exibited higher EAI than PMF (Figure 5a), this is likely due to pennisetin heating at $60^{\circ} \mathrm{C}$ during extraction. According to Pearce and Kinsella (1978), EAI of proteins is highly affected by temperature. In the mean time pennisetin had lower ES than PMF as shown in figure $5 \mathrm{~b}, \mathrm{ES}$ of both pennisetin and PMF were significantly different $(\mathrm{p} \leq 0.05)$. This is probably due to the non protein content in PMF such as starch, which may contribute to improve the stability of emulsions. Pennisetin EAI obtained in this study were two times lower than those obtained for sorghum kafirin (Amoura et al., 2020) and kidney bean proteins (Makeri et al., 2017) While pennisetin EAI was 9.5 to 3.5 times higher than those obtained for quinoa protein (1.24-3.38 $\mathrm{m}^{2} / \mathrm{g}$ ) (Dakhili et al., 2019) and comparable to sesame isolate $\left(16.8 \mathrm{~m}^{2} / \mathrm{g}\right)$ (Makeri et al., 2017). Emulsifying data of pennisetin and PMF obtained in the present study might increase their potential use as emulsifying enhancers in salad creams, sausage and mayonnaise.

Table 2 Gelation properties of pearl millet whole grain flour and pennisetin

\begin{tabular}{lcccccccccc}
\hline Concentration $\%(w / v)$ & 2 & 4 & 6 & 8 & 10 & 12 & 14 & 16 & 18 & 20 \\
\hline Pearl millet whole grain flour $* *$ & $0 \%^{\mathrm{a}}$ & $0 \%^{\mathrm{a}}$ & $0 \%^{\mathrm{a}}$ & $<50 \%^{\mathrm{a}}$ & $>50 \%^{\mathrm{ab}}$ & $>50 \%^{\mathrm{ab}}$ & $100 \%^{\mathrm{b}}$ & $100 \%^{\mathrm{b}}$ & $100 \%^{\mathrm{b}}$ & $100 \%^{\mathrm{b}}$ \\
Pennisetin & $0 \%$ & $0 \%$ & $0 \%$ & $0 \%$ & $0 \%$ & $0 \%$ & $0 \%$ & $0 \%$ & $0 \%$ & $0 \%$ \\
\hline Legend: $0 \%$, Not gelled; $<50 \%$, gelled less than $50 \% ;>50 \%$, gelled more than $50 \% ; 100 \%$ gelled. Values with the same letter in one row are not \\
significantly different from each other $(\mathrm{p} \leq 0.05) .{ }^{* * *} \mathrm{p} \leq 0.001, * * \mathrm{p} \leq 0.01,{ }^{*} \leq 0.05$.
\end{tabular}

Table 3 Foaming properties of pennisetin and pearl millet whole grain flour

\begin{tabular}{|c|c|c|c|c|c|c|c|c|c|c|c|c|c|}
\hline $\begin{array}{l}\text { Time } \\
(\min )\end{array}$ & 1 & 5 & 10 & 15 & 20 & 25 & 30 & 35 & 40 & 45 & 50 & 55 & 60 \\
\hline \multicolumn{14}{|c|}{ Pennisetin } \\
\hline $\begin{array}{l}\text { FC } \\
(\%)\end{array}$ & $\begin{array}{l}18.89^{\mathrm{b}} \\
\pm 1.11\end{array}$ & $\begin{array}{c}16.67^{\mathrm{a}, \mathrm{b}} \\
\pm 1.11\end{array}$ & $\begin{array}{c}16.67^{\mathrm{a}, \mathrm{b}} \\
\pm 1.11\end{array}$ & $\begin{array}{c}16.67^{\mathrm{a}, \mathrm{b}} \\
\pm 1.11\end{array}$ & $\begin{array}{c}16.67^{\mathrm{a}, \mathrm{b}} \\
\pm 1.11\end{array}$ & $\begin{array}{c}16.67^{\mathrm{a}, \mathrm{b}} \\
\pm 1.11\end{array}$ & $\begin{array}{c}16.67^{\mathrm{a}, \mathrm{b}} \\
\pm 1.11\end{array}$ & $\begin{array}{c}16.67^{\mathrm{a}, \mathrm{b}} \\
\pm 1.11\end{array}$ & $\begin{array}{c}16.67^{\mathrm{a}, \mathrm{b}} \\
\pm 1.11\end{array}$ & $\begin{array}{c}16.67^{\mathrm{a}, \mathrm{b}} \\
\pm 1.11\end{array}$ & $\begin{array}{c}15.56^{\mathrm{a}, \mathrm{b}} \\
\pm 2.22\end{array}$ & $\begin{array}{c}14.44^{\mathrm{a}, \mathrm{b}} \\
\pm 1.11\end{array}$ & $\begin{array}{l}11.11^{\mathrm{a}} \\
\pm 2.22\end{array}$ \\
\hline $\begin{array}{l}\text { FS**** } \\
(\%)\end{array}$ & $\begin{array}{l}100^{\mathrm{c}} \\
\pm 0.00\end{array}$ & $\begin{array}{c}100^{\mathrm{c}} \\
\pm 0.98\end{array}$ & $\begin{array}{c}88.19^{\mathrm{b}, \mathrm{c}} \\
\pm 0.98\end{array}$ & $\begin{array}{c}88.19^{\mathrm{b}, \mathrm{c}} \\
\pm 0.98\end{array}$ & $\begin{array}{c}88.19^{\mathrm{b}, \mathrm{c}} \\
\pm 0.98\end{array}$ & $\begin{array}{c}88.19^{\mathrm{b}, \mathrm{c}} \\
\pm 0.98\end{array}$ & $\begin{array}{l}88.19 \\
\pm 0.98\end{array}$ & $\begin{array}{c}88.19^{\mathrm{b}, \mathrm{c}} \\
\pm 0.98\end{array}$ & $\begin{array}{c}88.19^{\mathrm{b}, \mathrm{c}} \\
\pm 0.98\end{array}$ & $\begin{array}{c}88.19^{\mathrm{b}, \mathrm{c}} \\
\pm 0.98\end{array}$ & $\begin{array}{l}81.94^{\mathrm{b}} \\
\pm 9.82\end{array}$ & $\begin{array}{l}76.39^{\mathrm{b}} \\
\pm 1.96\end{array}$ & $\begin{array}{c}58.33^{\mathrm{a}} \\
\pm 11.79\end{array}$ \\
\hline \multicolumn{14}{|c|}{ Pearl millet whole grain flour } \\
\hline $\begin{array}{l}\text { FC } \\
(\%) \\
\text { FS** } \\
(\%) \\
\end{array}$ & $\begin{array}{l}7.78^{\mathrm{a}} \\
\pm 1.57 \\
100^{\mathrm{b}} \\
\pm 0.00\end{array}$ & $\begin{array}{c}5.56^{\mathrm{a}} \\
\pm 1.57 \\
70.83^{\mathrm{b}} \\
\pm 5.89 \\
\end{array}$ & $\begin{array}{c}5.56^{\mathrm{a}} \\
\pm 1.57 \\
70.83^{\mathrm{a}, \mathrm{b}} \\
\pm 5.89 \\
\end{array}$ & $\begin{array}{c}5.56^{\mathrm{a}} \\
\pm 1.57 \\
70.83^{\mathrm{a}, \mathrm{b}} \\
\pm 5.89 \\
\end{array}$ & $\begin{array}{c}5.56^{\mathrm{a}} \\
\pm 1.57 \\
70.83^{\mathrm{a}, \mathrm{b}} \\
\pm 5.89 \\
\end{array}$ & $\begin{array}{c}5.56^{\mathrm{a}} \\
\pm 1.57 \\
70.83^{\mathrm{a}, \mathrm{b}} \\
\pm 5.89 \\
\end{array}$ & $\begin{array}{c}5.56^{\mathrm{a}} \\
\pm 1.57 \\
70.83^{\mathrm{a}, \mathrm{b}} \\
\pm 5.89 \\
\end{array}$ & $\begin{array}{c}5.56^{\mathrm{a}} \\
\pm 1.57 \\
70.83^{\mathrm{a}, \mathrm{b}} \\
\pm 5.89 \\
\end{array}$ & $\begin{array}{c}5.56^{\mathrm{a}} \\
\pm 1.57 \\
70.83^{\mathrm{a}, \mathrm{b}} \\
\pm 5.89 \\
\end{array}$ & $\begin{array}{c}5.56^{\mathrm{a}} \\
\pm 1.57 \\
70.83^{\mathrm{a}, \mathrm{b}} \\
\pm 5.89 \\
\end{array}$ & $\begin{array}{c}5.56^{\mathrm{a}} \\
\pm 1.57 \\
70.83^{\mathrm{a}, \mathrm{b}} \\
\pm 5.89 \\
\end{array}$ & $\begin{array}{c}3.33^{\mathrm{a}} \\
\pm 1.57 \\
41.67^{\mathrm{a}} \\
\pm 11.79 \\
\end{array}$ & $\begin{array}{c}3.33^{\mathrm{a}} \\
\pm 1.57 \\
41.67^{\mathrm{a}} \\
\pm 11.79 \\
\end{array}$ \\
\hline
\end{tabular}

Legend: FC: Foam capacity; FS: Foam stability; Standard deviation between brackets; Values indicate the mean of three replicates (Standard Deviation). Values with the same letter in one row are not significatly different from each other $(\mathrm{p} \leq 0.05)$. ***p $\leq 0.001, * * \mathrm{p} \leq 0.01, * \mathrm{p} \leq 0.05$. 

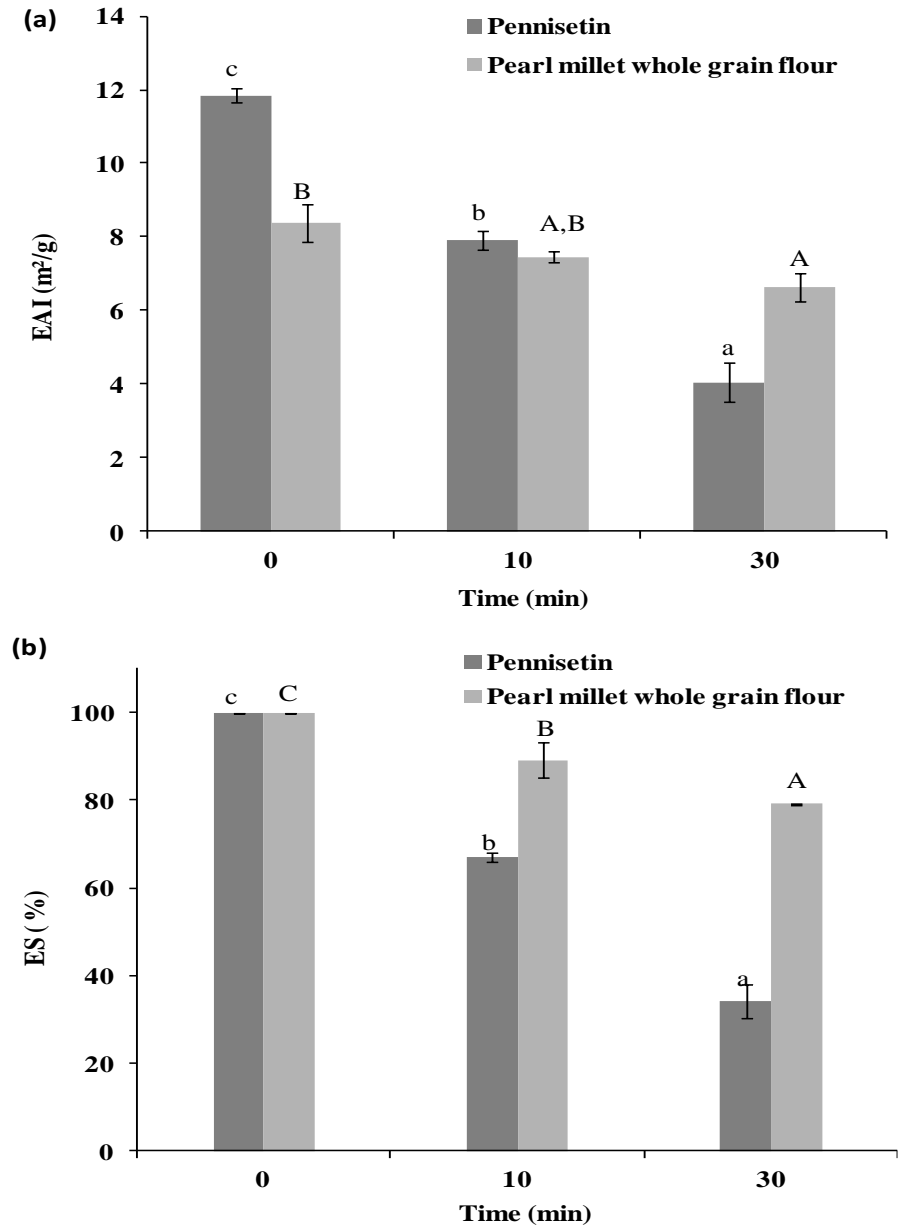

Figure 5 Emulsifying properties of pennisetin and pearl millet whole grain flour (a) Emulsifying activity index (EAI) and (b) Emulsion stability (ES). Values with the same letter (lowercase, uppercase) are not significantly different from each other $(\mathrm{p} \leq 0.05)$

\section{CONCLUSION}

In the present study the effect of temperature, adding reducing agent and $\mathrm{NaOH}$ on the extraction of the alcohol soluble pearl millet proteins (pennisetin) was investigated. The best conditions were found to be the following $70 \%$ aqueous ethanol containing $0.2 \% \mathrm{NaOH}$ and $1 \% \mathrm{MBS}$ at $60^{\circ} \mathrm{C}$. To the best of our knowledge, this solvent allowed extracting the highest percentage of pennisetin with protein content exceeding $90 \%$ and higher level of essential AA $(68.55 \%)$ than PMF $(41.64 \%)$

Compared to sorghum, soybean, wheat and rice flours, PMF exhibited higher or in the same range OBC and slightly lower WBC. While, WBC and OBC of pennisetin were lower than cereal protein isolates such as kafirin and quinoa protein isolate. Pennisetin had no ability to form a gel while the LGC of PMF was better than sorghum, wheat and rice flours. Foaming and emulsifying properties of pennisetin were better than PMF with better FS and lower ES. According to their functional properties, PMF and pennisetin could be used as gluten free additive for better food sensorial perception and texture and as emulsifying or foaming enhancers. These results could be a starting point to increase the use of pearl millet as a gluten free cereal particularly its alcohol soluble proteins: pennisetin for food, feed and non food applications for celiac patients.

\section{REFERENCES}

Abdel-Aal, E. S. M., \& Hucl, P. (2002). Amino acid composition and in vitro protein digestibility of selected ancient wheats and their end products. Journal of Food Composition and Analysis, 15(6), 737-747. https://doi.org/10.1006/jfca.2002.1094

Adebiyi, J. A., Obadina, A. O., Adebo, O. A., \& Kayitesi, E. (2017). Comparison of nutritional quality and sensory acceptability of biscuits obtained from native, fermented, and malted pearl millet (Pennisetum glaucum) flour. Food Chemistry, 232, 210-217. https://doi.org/10.1016/j.foodchem.2017.04.020

Akinola, S. A., Badejo, A. A., Osundahunsi, O. F., \& Edema, M. O. (2017) Effect of preprocessing techniques on pearl millet flour and changes in technological properties. International Journal of Food Science and Technology, 52(4), 992-999. https://doi.org/10.1111/ijfs.13363
Akharume, F., Santra, D., \& Adedeji, A. (2020). Physicochemical and functional properties of proso millet storage protein fractions. Food Hydrocolloids, 108 , 105497. https://doi.org/10.1016/j.foodhyd.2019.105497

Ali, M. A. M., Tinay, A. H. El, Elkhalifa, A. E. O., Mallasy, L. O., \& Babiker, E. E. (2012). Effect of different supplementation levels of soybean flour on pearl millet functional properties. Food and Nutrition Sciences, 3, 1-6.

American Association of Cereal Chemists International. (2000) AACC Approved Methods of the American Association of Cereal Chemists. Method 44-15A. 10th ed., St. Paul. (MN).USA

Amoura, H., Mokrane, H., \& Nadjemi, B. (2020). Effect of wet and dry milling on the functional properties of whole sorghum grain flour and kafirin. Journal of Food Science and Technology, 57(3), 1100-1109. https://doi.org/10.1007/s13197-019-04145-2

Association of Official Analytical Chemists. (1990) AOAC Official Methods of Analysis. 15th ed. Washington DC. USA.

Bean, S. R., Ioerger, B. P., Park, S. H., \& Singh, H. (2006). Interaction between sorghum protein extraction and precipitation conditions on yield, purity, and composition of purified protein fractions. Cereal Chemistry, 83(1), 99-107. https://doi.org/10.1094/CC-83-0099

Beuchat, L. R. (1977). Functional and electrophoretic characteristics of succinylated peanut flour protein. Journal of Agricultural and Food Chemistry, 25(2), 258-261. doi: 10.1021/jf60210a044.

Bora, P., Ragaee, S., \& Marcone, M. (2019). Characterisation of several types of millets as functional food ingredients. International Journal of Food Sciences and Nutrition, 70(6), 714-724. https://doi.org/10.1080/09637486.2019.1570086

Bugs, M. R., Forato, L. A., Bortoleto-Bugs, R. K., Fischer, H., Mascarenhas, Y. P., Ward, R. J., \& Colnago, L. A. (2004). Spectroscopic characterization and structural modeling of prolamin from maize and pearl millet. European Biophysics Journal, 33(4), 335-343. https://doi.org/10.1007/s00249-003-0354-3 Celus, I. Brijs, K. \& Delcour, J. A. (2009). Fractionation and characterization of brewers' spent grain protein hydrolysates. Journal of Agricultural and Food Chemistry, 57(12), 5563-5570. https://doi.org/10.1021/jf900626j

Chandna, M., \& Matta, N. K. (1990). Characterization of pearl millet protein fractions. Phytochemistry, 29(11), 3395-3399.

Coffmann, C. W., \& Garcia, V. V. (1977). Functional properties and amino acid Journal of Food Technology, 12(November), 473-484.

Dakhili, S., Abdolalizadeh, L., Hosseini, S. M., Shojaee-aliabadi, S., \& Mirmoghtadaie, L. (2019). Quinoa protein: composition, structure and functional properties. Food Chemistry, August, 125-161. https://doi.org/10.1016/i.foodchem.2019.125161

De Brier, N., Gomand, S. V., Celus, I., Courtin, C. M., Brijs, K., \& Delcour, J. A. (2015). Extractability and chromatographic characterization of wheat (Triticum aestivum L.) bran protein. Journal of Food Science, 80(5), C967-C974. https://doi.org/10.1111/1750-3841.12856

Dhankhar, J., Vashistha, N., \& Sharma, A. (2019). Development of biscuits by partial substitution of refined wheat flour with chickpea flour and date powder. Journal of Microbiology, Biotechnology and Food Sciences, 8(4), 1093-1097.

https://doi.org/10.15414/jmbfs.2019.8.4.1093-1097

Esfandi, R., Walters, M. E., \& Tsopmo, A. (2019). Antioxidant properties and potential mechanisms of hydrolyzed proteins and peptides from cereals. Heliyon 5(4), e01538. https://doi.org/10.1016/j.heliyon.2019.e01538

Espinosa-Ramírez, J., \& Serna-Saldívar, S. O. (2016). Functionality and characterization of kafirin-rich protein extracts from different whole and decorticated sorghum genotypes. Journal of Cereal Science, 70, 57-65. https://doi.org/10.1016/j.jcs.2016.05.023

FAO/WHO: Food and Agriculture Organization/World Health Organization. (1991) FAO/WHO Nutrition Meetings, Report Series 51, Viale delle Terme di Caracalla, FAO, Rome, Italy.

Gessendorfer, B., Wieser, H., \& Koehler, P. (2010). Optimisation of a solvent for the complete extraction of prolamins from heated foods. Journal of Cereal Science, 52(2), 331-332. https://doi.org/10.1016/j.jcs.2010.04.010

Gwamba, J., Kruger, J., \& Taylor, J. R. N. (2019). Influence of grain quality characteristics and basic processing technologies on the mineral and antinutrien contents of iron and zinc biofortified open-pollinated variety and hybrid-type pearl millet. International Journal of Food Science and Technology, 1-12 https://doi.org/10.1111/ijfs.14375

Hadimani, N. A., Muralikrishna, G., Tharanathan, R. N., \& Malleshi, N. G (2001). Nature of Carbohydrates and Proteins in Three Pearl Millet Varieties Varying in Processing Characteristics and Kernel Texture. Journal of Cereal Science, 33(1), 17-25. https://doi.org/10.1006/JCRS.2000.0342

Hajas, L., Scherf, K. A., Török, K., Bugyi, Z., Schall, E., Poms, R. E., Koehler, P., \& Tömösközi, S. (2018). Variation in protein composition among wheat (Triticum aestivum L.) cultivars to identify cultivars suitable as reference material for wheat gluten analysis. Food Chemistry, 267, 387-394. https://doi.org/10.1016/j.foodchem.2017.05.005

Hamaker, B. R., Mohamed, A. A., Habben, J. E., Huang, C. P., \& Larkins, B. A (1995). Efficient procedure for extracting maize and sorghum kernel proteins reveals higher prolamin contents than the conventional method. Cereal Chemistry, 72(6), 583-588. 
Harrigan, G. G., Stork, L. A. G., Riordan, S. G., Reynolds, T. L., Taylor, J. P., Masucci, J. D., Cao, Y., LeDeaux, J. R., Pandravada, A., \& Glenn, K. C. (2009). Impact of environmental and genetic factors on expression of maize gene classes: Relevance to grain composition. Journal of Food Composition and Analysis, 22(2), 158-164. https://doi.org/10.1016/i.jfca.2008.08.005

Hassan, A. B., Osman, G. A., \& Babiker, E. E. (2007). Effect of chymotrypsin digestion followed by polysaccharide conjugation or transglutaminase treatment on functional properties of millet proteins. Food Chemistry, 102, 257-262. https://doi.org/10.1016/j.foodchem.2006.04.043

Joshi, A. U., Liu, C., \& Sathe, S. K. (2015). Functional properties of select seed fl ours. LWT - Food Science and Technology, 60(1), 325-331. https://doi.org/10.1016/j.lwt.2014.08.038

Kamara, M. T., Amadou, I., Tarawalie, F., \& Huiming, Z. (2010). Effect of enzymatic hydrolysis on the functional properties of foxtail millet (Setaria italica L.) proteins. International Journal of Food Science and Technology, 45(6), 1175-1183. https://doi.org/10.1111/j.1365-2621.2010.02260.x

Kamara, M. T., Zhu, K., Issoufou, A., Tarawalie, F., \& Zhou, H. (2009). Functionality, in vitro digestibility and physicochemical properties of two varieties of defatted foxtail millet protein concentrates. International Journal of Molecular Sciences, 10(12), 5224-5238. https://doi.org/10.3390/ijms10125224

Kasaoka, S., Oh-hashi, A., Morita, T., \& Kiriyama, S. (1999). Nutritional characterization of millet protein concentrates produced by a heat-stable a amylase digestion. . 19:899-910. Nutcitioe Research, 19(6), 899-910.

Makeri, M. U., Abdulmannan, F., Ilowefah, M. A., Chiemela, C., Bala, S. M., \& Muhammad, K. (2017). Comparative physico-chemical, functional and structura characteristics of winged bean [Psophocarpus tetragonolobus DC] and Soybean [Glycine max.] Protein isolates. Journal of Food Measurement and Characterization, 11(2), 835-846. https://doi.org/10.1007/s11694-016-9455-4

Marcellino, L., Junior, C., \& Gander, E. (2005). Characterization of Pearl Millet Prolamins. Protein \& Peptide Letters, 9(3), 237-244. https://doi.org/10.2174/0929866023408724

Mokrane, H. (2010). Isolation, purification and characterization of proteins in algerian cultivars of pearl millet [ Pennisetum glaucum ( $L$.) $R . B r$ ] and sorghum [ Sorghum bicolor ( $L$.) Moench ]. PhD Bioscience engineering. KULeuven.

Mokrane, H., Amoura, H., Belhaneche-Bensemra, N., Courtin, C. M., Delcour, J A., \& Nadjemi, B. (2010). Assessment of Algerian sorghum protein quality [Sorghum bicolor (L.) Moench] using amino acid analysis and in vitro pepsin digestibility. Food Chemistry, 121(3), https://doi.org/10.1016/i.foodchem.2010.01.020

Mokrane, H., Lagrain, B., Gebruers, K., Courtin, C. M., Brijs, K., Proost, P., \& Delcour, J. A. (2009). Characterization of kafirins in algerian sorghum cultivars Cereal Chemistry, 86(5), 487-491. https://doi.org/10.1094/CCHEM-86-5-0487 Nałęcz, D., Dziuba, M., \& Szerszunowicz, I. (2017). Isolation of oat (Avena sativa L.) total proteins and their prolamin fractions for $2 \mathrm{D}$ electrophoresis. In Methods in Molecular Biology (Vol. 1536, pp. 225-234) https://doi.org/10.1007/978-1-4939-6682-0_16

Oshodi, A. A., Ogungbenle, H. N., \& Oladimeji, M. O. (1999). Chemical composition, nutritionally valuable minerals and functional properties of benniseed ( Sesamum radiatum ), pearl millet ( Pennisetum typhoides ) and quinoa ( Chenopodium quinoa ) flours. International Journal of Food Sciences and Nutrition, 50(5), 325-331.

Ozturk, A., \& Aydin, F. (2004). Effect of Water Stress at Various Growth Stages on Some Quality Characteristics of Winter Wheat Effect of Water Stress a Various Growth Stages on Some Quality Characteristics of Winter Wheat Journal of Agronomy and Crop Science, 190, 93-99. https://doi.org/10.1046/j.1439-037X.2003.00080.x

Park, S.-H., \& Bean, S. R. (2003). Investigation and Optimization of the Factors Influencing Sorghum Protein Extraction. Journal of Agricultural and Food Chemistry, 51, 7050-7054.

Pearce, K. N., \& Kinsella, J. E. (1978). Emulsifying properties of proteins: Evaluation of a turbidimetric technique. Journal of Agricultural and Food Chemistry, 26(3), 716-723.

Pontieri, P., Troisi, J., Bean, S. R., Tilley, M., Di Salvo, M., Boffa, A., Pignone, D., Del Giudice, F., Aletta, M., Alifano, P., \& Del Giudice, L. (2019), Comparison of extraction methods for isolating kafirin protein from food grade sorghum flour. Australian Journal of Crop Science, 13(8), 1297-1304. https://doi.org/10.21475/ajcs.19.13.08.p1695

R Core Team (2020). R: A language and environment for statistical computing. R Foundation for Statistical Computing, Version R 4.0.2 URL https://www.Rproject.org/.

Ranasalva, N., \& Visvanathan, R. (2014). Development of cookies and bread from cooked and fermented pearl millet flour. African Journal of Food Science, 8(6), 330-336. https://doi.org/10.5897/AJFS2013.1113

Redant, L., Buggenhout, J., Brijs, K., \& Delcour, J. A. (2017). Extractability and chromatographic separation of rye (Secale cereale L.) flour proteins. Journal of Cereal Science, 73, 68-75. https://doi.org/10.1016/j.jcs.2016.11.010

Ricks, C. B. (2007). The prolamins of pearl millet. Master of Science. Brigham Young University.
Rombouts, I., Lamberts, L., Celus, I., Lagrain, B., Brijs, K., \& Delcour, J. A. (2009). Wheat gluten amino acid composition analysis by high-performance anion-exchange chromatography with integrated pulsed amperometric detection. $\begin{array}{lll}\text { Journal of Chromatography A, 1216(29), 5557-5562. } & \end{array}$ https://doi.org/10.1016/i.chroma.2009.05.066

Sarita, S. E. (2016). Potential of Millets: Nutrients Composition and Health Benefits. Journal of Scientific and Innovative Research JSIR, 5(52), 46-50.

Sathe, S. K., Deshpande, S. S., \& Salunkhe, D. K. (1982). Functional Properties of Lupin Seed (Lupinus mutabilis) Proteins and Protein Concentrates. Journal of Food Science, 47(2), 491-497. https://doi.org/10.1111/i.13652621.1982.tb10110.x

Sainani, M. N., Lachke, A. H., Sahasrabudhe, N. A., \& Ranjekar, P. K. (1989). Viscometric characterization of pennisetin from pearl millet. Biochemical and Biophysical Research Communications, 165(1), 334-341.

Schalk, K., Lexhaller, B., Koehler, P., \& Scherf, K. A. (2017). Isolation and characterization of gluten protein types from wheat, rye, barley and oats for use as reference materials. PLoS ONE, 12(2), 1-20. https://doi.org/10.1371/journal.pone.0172819

Simwaka, J. E., Chamba, M. V. M., Huiming, Z., Masamba, K. G., \& Luo, Y. (2017). Effect of fermentation on physicochemical and antinutritional factors of complementary foods from millet, sorghum, pumpkin and amaranth seed flours International Food Research Journal, 24(5), 1869-1879.

Taylor, J. R. N., Taylor, J., Campanella, O. H., \& Hamaker, B. R. (2016) Functionality of the storage proteins in gluten-free cereals and pseudocereals in dough systems. Journal of Cereal Science, 67, 22-34 https://doi.org/10.1016/j.jcs.2015.09.003

Wu, H., Wang, Q., Ma, T., \& Ren, J. (2009). Comparative studies on the functional properties of various protein concentrate preparations of peanut protein. Food Research International, 42(3), 343-348. https://doi.org/10.1016/j.foodres.2008.12.006

Zayas, J. F. (1997). Functionality of proteins in food. Springer-Verlag Berlin Heidelberg GmbH. http://download.springer.com/static/pdf/185/bfm\%253A9783-642-56668-

4\%252F1.pdf?auth66=1401995374_4d363c462609ae19e3de18b0ee51ef07\&ext= . $\mathrm{pdf}$ 